\title{
IGCP in Africa: Workshop on skills development in preparing project applications
}

\author{
26-28 July 2011, UN Complex Gigiri, Nairobi, Kenya
}

\author{
Main challenges of Earth sciences in \\ Africa
}

The UNESCO's Earth Science Education Initiative in Africa (ESEIA) is probably one of the most important legacies of the International Year of Planet Earth (IYPE). ESEIA was announced by the Director General of UNESCO at the occasion of the Africa Regional Launch of IYPE in Arusha (Tanzania) in 2008. The overall intention of this initiative is to support the development of the next generation of earth scientists in Africa who are equipped with the necessary tools, networks and perspectives to apply sound science to solving and benefiting from the challenges and opportunities of sustainable development ${ }^{1}$. The opportunities in the earth sciences are great, starting with traditional mineral extraction and extending into environmental management such as climate change adaptation, prevention of natural hazards, and ensuring access to drinking water. As a follow-up to the announcement from the Director General of UNESCO, five regional scoping workshops were organized between October 2009 and February 2010 to assess regional capacities and needs in Earth science education, research and industry. These workshops have highlighted some major challenges facing the earth sciences in Africa, among them, the lack of analytical facilities, the isolation facing many researchers and the low level of cooperation between earth science institutions in the region ${ }^{2}$.

This preliminary assessment was completed by two other surveys. The first looked into the performance of African earth scientists in the International Geoscience Programme $(\mathrm{IGCP})^{3}$. It revealed the marginal involvement of Africa in IGCP since its launch in 1972, both in terms of number of projects devoted to the continent (only 7\%) and in terms of the number of project leaders from the continent (5\%). The second survey ${ }^{4}$ looked into the performance of African earth scientists in the area of publications, using the case of the Journal of African Earth Sciences (JAES) - an international journal fully devoted to African Geology and covering all the fields of earth sciences. The

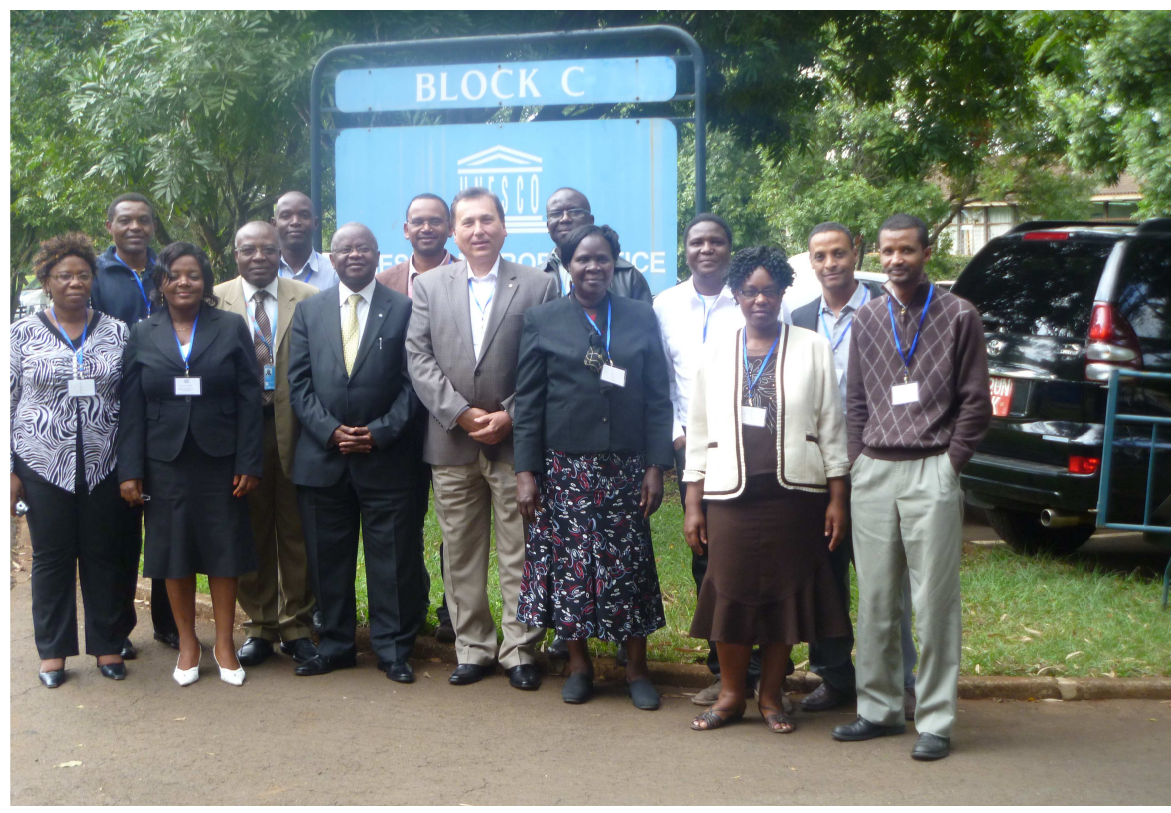

Participants at the workshop, from left to right at the front: Therese Ntonzi Nganje (Nigeria), Caroline Neh Ngwa (Cameroon), Joseph Massaquoi (Director of UNESCO Nairobi office), Yildirim Dilek (USA), Monica Omulo (Kenya), Maideyi Lydia Meck (Zimbabwe), Asrat Asfawossen (Ethiopia); from left to right at the back: Kankeu Boniface (Cameroon), Sadrack Felix Toteu (UNESCO Nairobi), Michael Owor (Uganda), Daud Jamal (Mozambique), Florent Boudzoumou (Republic of Congo), Mousa Isseini (Chad) and Ousmane Wane (Mali).

survey revealed that only $48 \%$ of total authors of the articles published in JAES during the period 2000-2010 are affiliated to an African institution. This is less than what would have been expected from a journal fully devoted to African earth science research; also, about $86.5 \%$ of Africa's contribution is from only ten countries, among which the four countries contribute more than $62 \%$ (Morocco, South Africa, Egypt, and Cameroon). This unequal distribution of outputs emphasizes the need to foster earth science research in the majority of countries. Finally, the survey revealed the low level of co-authoring between reaserchers from African institutions, indicating the need of promoting more cooperative research amongst African researchers and African institutions.

Looking at its potential as a significant driver of earth science research, UNESCO and the African earth science community have considered IGCP to be a critical focus if earth science research is to be promoted in Africa. During the $23^{\text {rd }}$ Colloquium of African
Geology held in Johannesburg in January 2011, the General Assembly of the Geological of Africa adopted a resolution sensitising the African community to the importance of IGCP and on the necessity of revitalising or creating IGCP National Commissions in African countries. Thanks to special funding from the Swedish International Developing Agency (SIDA), UNESCO has embarked on a more vigorous promotion of this internationally recognised programme in Africa, especially through the "Young Scientist IGCP" scheme. During the IGCP Board meeting of February 2011, three projects devoted to Africa were approved for four-year SIDA funding.

\section{IGCP Workshop in Nairobi (Kenya)}

The workshop was held in the UNESCO Nairobi office and was funded by both the Swedish International Development Agency (SIDA) and by the regular budget of Earth Sciences of UNESCO Nairobi office. This event was part of UNESCO's efforts 
to promote IGCP in Africa and aimed to develop the skills of successful proposal writing, with the overall goal of increasing the number and the quality of IGCP proposals from African earth scientists during the next IGCP scientific board meetings. A call for participation was sent out in March 2011 and the deadline for application was set for 30 May 2011. Each applicant had to submit a project proposal using IGCP format. Out of 16 applications received, 11 were selected and invited to the workshop. Professor Yildirim Dilek of Miami University, Oxford, USA and Member of the IGCP Scientific Board and Dr S. Felix Toteu, Earth Science Specialist at the UNESCO Nairobi office, and leader of the highly successful IGCP project 470 , served as facilitators during the workshop. The programme of the workshop was designed to be as informal as possible and to allow intense discussion among participants. The 3-day workshop focused on introductory presentations by the facilitators, presentations on individual projects by participants, break-out discussions, and general synthesis and lessons learnt.

\section{Opening ceremony}

During the opening address of Prof. Massaquoi, Director of the UNESCO Nairobi office, the importance was stressed of the revitalization of earth science activities in the Nairobi office and on the huge research and collaborative opportunities participants would gain from this workshop.

\section{Introductive presentations}

The first introductory presentation was made by Felix Toteu on "The International Geosciences Programme in Africa". He revisited the history of IGCP, its structure including the IGCP National Committees, how IGCP works, and discussed why IGCP has not been successful in Africa. He finally elaborated on how UNESCO is planning to promote IGCP in the continent.

The second introductory paper was made by Yildirim Dilek on "Preparing an IGCP Proposal". It went into detail on the process of elaborating a successful project using the different sections of the IGCP form. This allowed him to stress the evaluation process and what makes a proposal successful. In the African context, he insisted on aspects like project objectives, potential collaboration, and work plan including scientifically relevant field trips.

The third introductory presentation was

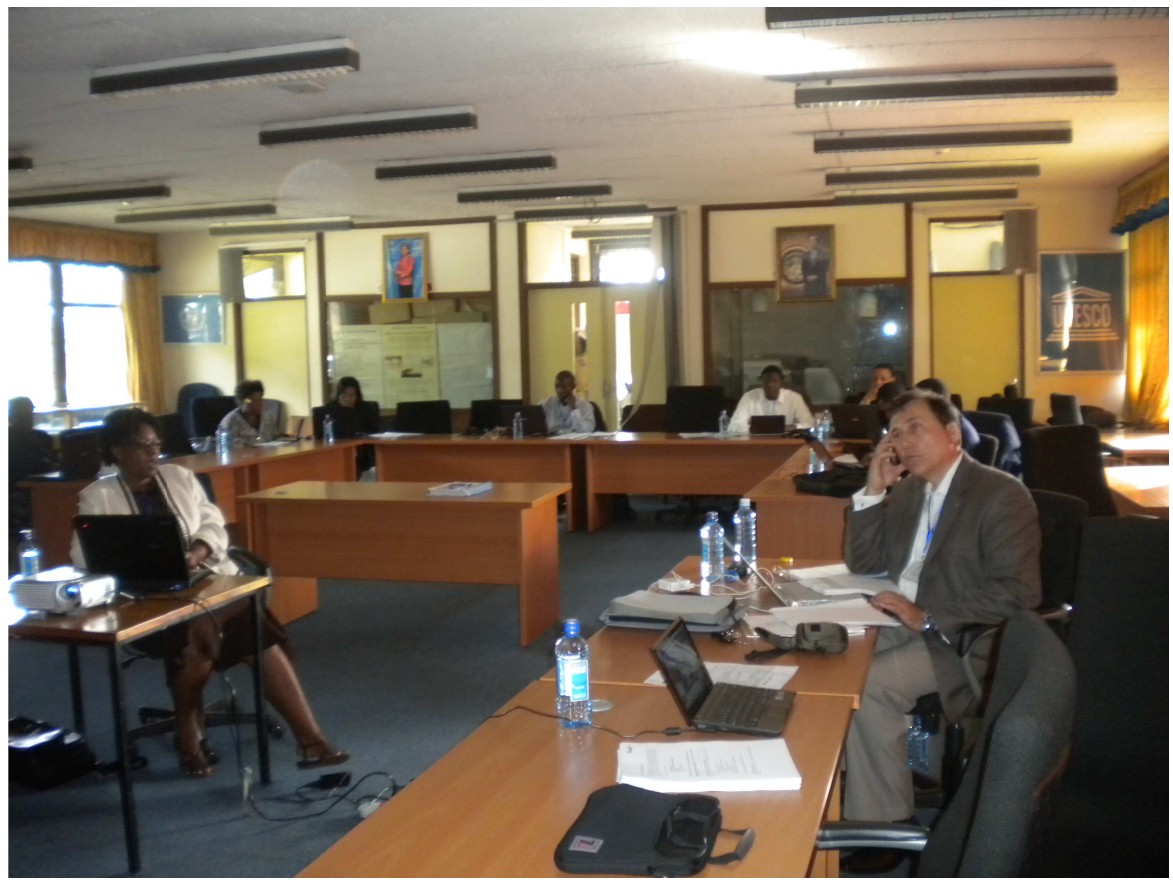

Participants at the plenary session.

made by Felix Toteu on "Lessons learnt from IGCP-470". This presentation was used as a show-case of a project prepared and implemented in a context of many challenges faced by most African earth scientists. He discussed 10 ingredients for a successful IGCP in Africa including securing: core participants from Africa and abroad, support from ones' home institution, support from region partner institutions in running field trips, international partnership for laboratory work, efficient use of UNESCO/IUGS seed money, connection with industries. He also highlighted a few cases of career boosting for young scientists involved in IGCP-470. He also stressed on the potential of magnifying the project funding thanks to the UNESCOIUGS endorsement.

\section{Projects presentation by participants}

Each participant was invited to present the project he or she intended to submit for IGCP funding. A total of 11 proposals were presented, each of them followed by discussion. The proposals presented fell into the following IGCP Major Themes:

\section{Deep Earth theme:}

- The Panafrican Mayombe (West Congo) fold belt and the adjacent Niari basin in the Central Africa: Geodynamic history, ore deposits context and paleomagnetism study by Florent Boudzoumou from the Republic of Congo;

Neoproterozoic evolution of the conti- nental crust: Geodynamic and metallogenic aspects by Moussa Isseini from Chad.

- Magmatic and tectonic evolution of the Mesoproterozoic Fingoe Fold Belt by Daud Jamal from Mozambique

- Tectonic, geomorphology and landscape evolution of central Cameroon by Boniface Kankeu from Cameroon

- Basaltic magmatic systems in intraplate settings: Insights into Magma Chamber Characteristics and Magma Evolution beneath Mt. Cameroon by Caroline Neh Ngwa from Cameroon

- Correlation of stratigraphic and intrusive units of the Massigui regions south Mali) Fada N'Gourma (eastern Burkina Faso) and Diaforou-Drbani (south western Niger) regions : geodynamics of the northern and northeastern borders of Birrimian Man domain of Man by Ousmane Wane from Mali.

Global Changes and Evolution of Life:

- Monitoring cave climate, surface and groundwater geochemistry in East Africa: implication for speleothem paleoclimate studies by Kassaye Asfawossen Asrat from Ethiopia

Geohazards:

- Temporal Assessment of potentially toxic elements in shale rock, in parts of Southern Benue Trough, Nigeria by Therese Ntonzi Nganje from Nigeria 
Earth resources:

- Sustainable utilization of minerals for agricultural purposes to enhance future well-being of society by Maideyi Lydia Meck from Zimbabwe

\section{Ground Water:}

- Sustainable groundwater development for agricultural (irrigation) support in semiarid regions of Uganda by Michael Owor from Uganda

A last proposal initiated by the Association of African Women Geoscientists (AAWG) was related to Geopark development in the Lake Victoria basin (Kenya) and the impact of climate change presented by Monica Omulo from Kenya

\section{Break-out discussions}

After the individual presentation by participants, the debate that followed showed that most projects need to be reviewed to make them really international and to be consistent with IGCP goals. Participants were invited to make sure that their proposal shows clear international potential both in terms of the topic of research and of participation. In this regard the quality of some proposals presented could be enhanced if they were merged into only one proposal based on the following guidelines: (1) have a more attractive title; (2) define four or five clear objectives; (3) make the proposal truly international in terms participants and of institutional partnerships essential for laboratory data production; and (4) identify internationally attractive field trips. The constitution of the break-out groups was defined based on this strategy. Group-1

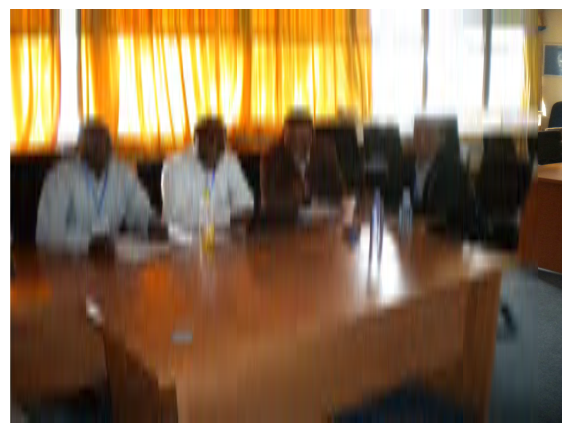

Participants at the break-out Group-1.

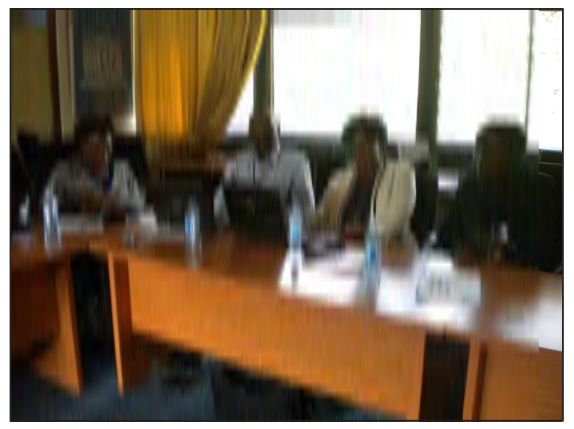

Participants at the break-out group-2.

included the presenters of proposals of the Deep Earth Theme and Group-2 included the presenters of proposals falling in the Geohazard, Earth Resource and Groundwater Themes. All projects standing alone benefited from an intensive review and redrafting of the text during the discussions.

Deliberations in Group-1 led to the merger of all proposals into a very encouraging research theme on "Proterozoic stabilisation and remobilisation of cratons in Africa: Geodynamics and metallogenesis", with the objectives to (1) contribute to the understanding of those processes linked to cratonic stabilization and reactivation/ remobilisation during the Proterozoic in Africa, (2) understand deep processes and mantle-crust interactions during successive orogenic cycles that built the Precambrian architecture of the African continent, and (3) clarify geodynamics and metallogenesis links within the frame of the above considered processes. Field trips during the proposed 5year project are designed to cover the main period of crustal building in Africa-the Archean and Proterozoic cratonic terranne with a show case in West Africa, Burkina Fasso and Mali; the Proterozoic belt in Mozambique; the Neoproterozoic belts in Central Africa, Chad and Cameroon); and the Neoproterozoic crustal growth in NE Africa. Group-2 also came out with similar type of result with a merged proposal entitled "Earth resources for poverty alleviation, health in Africa".

\section{Lessons learnt}

An important lesson learnt from this workshop is the very high awareness amongst Africans of the need to break their isolation and move from individual and local research projects to regional and international projects. This active outward looking perspective is the only way to be connected to the international earth sciences community and to generate research proposals with the potential of attracting other colleagues and interest from research teams and laboratories abroad. In this regard, participants agreed to maintain the network created during this workshop to exchange information and continue to develop stand alone and merged proposals in view of submission to the IGCP funding.

\section{Acknowledgement}

The organization of this workshop has been made possible by a special funding from the Swedish International Development Agency (SIDA) and UNESCO Nairobi office. We extend our special thanks to the UNESCO Nairobi staff who contributed to a successful organization of the workshop.

\section{S. Felix Toteu}

Earth Sciences Unit

UNESCO Nairobi Office, Kenya

E-mail: sf.toteu@unesco.org

\section{Quoted documents}

${ }^{1}$ UNESCO Project Brief: Earth Science Education Initiative in Africa: http:// www.unesco.org/new/fileadmin/ MULTIMEDIA/HQ/SC/pdf/GEO_ScEd-Initiative-Africa_Project-Brief_052011_en.pdf

${ }^{2}$ Earth Sciences Education Initiative in Africa: Scoping workshops synthesis, 10 June 2010. http://www.unesco.org/new/ fileadmin/MULTIMEDIA/HQ/SC/pdf/ GEO_eseia_synthesis-10june_en.pdf

${ }^{3}$ IGCP in Africa workshop on skills development. http://www.servirglobal.net/tabid/ 205/Article/950/call-for-applicationsigcp-in-africa-workshop-on-skillsdevelopment.aspx,18 May 2011.

${ }^{4}$ UNESCO Nairobi report on "The Performance of African Earth Scientists in the Journal of African Earth Sciences (JAES) during the Period 2000-2010”. Prepared by Asrat Asfawossen, consultant, October 2011. 